\author{
Case Study
}

www.ijrap.net

(ISSN Online:2229-3566, ISSN Print:2277-4343)

\title{
MANAGEMENT OF TENNIS ELBOW BY VIDDAGNIKARMA: A CASE STUDY
}

\author{
Poornima Jalawadi ${ }^{1}$, Deepa Patil ${ }^{2}$, Shivakumara Aladakatti ${ }^{3 *}$ \\ ${ }^{1}$ Associate Professor, Department of PG Studies in Shalyatantra, JSS Ayurveda Medical College and Hospital Mysuru, \\ Karnataka, India \\ ${ }^{2}$ Professor, Department of PG Studies in Kayachikitsa, JSS Ayurveda Medical College and Hospital Mysuru, \\ Karnataka, India \\ ${ }^{3}$ PG Scholar, Department of PG Studies in Shalyatantra, JSS Ayurveda Medical College and Hospital Mysuru, \\ Karnataka, India
}

Received on: 19/10/21 Accepted on: 18/01/22

\author{
*Corresponding author \\ E-mail: Shivakumatka8@g,mail.com
}

DOI: $10.7897 / 2277-4343.13013$

\begin{abstract}
Agnikarma is one of the Para surgical procedures in Ayurveda. It gives instant and long-lasting results. Agnikarma is indicated in Vata and Kapha's diseases and some painful conditions that involve the musculoskeletal system that comprises Sandhi, Asthi, Sira and Snayus. Tennis elbow or Lateral epicondylitis is a painful disease that causes restricted forearm movements. Only symptomatic treatments are available to date, which comprises Analgesics, Anti-inflammatory drugs, Physiotherapy, steroid injections, exercise etc. But none of them has satisfactory results. And causes some adverse effects by long term usage of these Analgesics and Anti-inflammatory drugs. In Ayurveda, Tennis elbow can correlate with Snayugatavata based on the symptoms. Agnikarma is indicated in this condition as told by Acharya Sushruta. Different Acharyas Suchi explained various Dahanopakaranas is one among them, which Acharya Chakra Datta. In this study, Tennis elbow was treated by Agnikarma using needles and electro-cautery along with Triphala Guggulu orally for seven days. It gives considerable relief from pain and movement of the elbow joint.
\end{abstract}

Keywords: Viddhagnikarma, Snayugatavata, Tennis elbow, Triphala Guggulu.

\section{INTRODUCTION}

Tennis elbow is a painful condition it affects the forearm. It is due to nonspecific inflammation at the origin of the extensor muscle of the forearm ${ }^{1}$. It is diagnosed based on clinically pain sensation, particularly movements like pouring tea, turning off the stiff door handle, etc. Tenderness at the lateral epicondyle of the humerus. It is aggravated during activities that involve the forearm. The prevalence rate of tennis elbow is $1-3 \%{ }^{2}$. In young age group considering 40-60 years are more prone to this disease. The general cause for Tennis elbow is excess usage of the forearm for household activities, non-recognised or minor trauma ${ }^{3}$, and weight lifting. Mainly the disease was found in tennis players 4 . But now a day it also affects plumbers, carpenters, painters, automobile workers and cooks ${ }^{5}$. The dominant arm is more prone to this disease than the non-dominant one.

Based on signs and symptoms, it is compared to Snayugatavata in Ayurveda. It is developed when Vata gets aggravated due to vatakara Ahara-Vihara ${ }^{6}$ and is localised in Snayu of Kurpara Sandhi (elbow), causing pain, stiffness, restricted movements. Tennis elbow is a self-limiting disease, and $90 \%$ of cases show good recovery with a conservative line of treatment ${ }^{7,8}$ and less than $10 \%$ Cases needs surgery. In modern science, some medications like Anti-inflammatory, analgesics and steroid injections are indicated. Long term usage of these medications leads to adverse effects on the body. Some of the surgical procedures are also there with their limitations.
In Ayurveda, Acharya Sushruta explains various treatment modalities, including Snehaha, Upanaha, Agnikarma and Bandana ${ }^{9}$. In that Suchividdha Agnikarma with the usage of bipolar electrocautery is one of the modified Agnikarma techniques based on Acharya Chakra Datta. It seems to be very effective in instant pain relief and stiffness.

\section{CASE REPORT}

A female patient of 40 years old with Vata-Kaphaja Prakruti visited our OPD of Shalya tantra department of JSS Ayurveda hospital, mysuru on $10^{\text {th }}$ January 2021 with the complaints of pain, stiffness and restricted movements of the lateral part of the right elbow joint for two months. The patient did not have any systemic disorders. There is no history of trauma. It was elicited that the patient could not do the household work, especially mopping the floors, ironing and lifting the buckets, etc. The surgeon noticed maximum pain and tenderness at the lateral epicondyle of the humerus of the right elbow without swelling. The patient experienced more pain during flexion, extension and lateral rotation of the right hand. All the routine blood investigations, including the RA factor (Rheumatoid factor) and X-ray of the right elbow, were taken. All the investigations were found to be expected. Based on these factors patient was diagnosed with tennis elbow.

After proper examination and assessment of the patient, Suchividdha Agnikarma was carried out using bipolar electric cautery along with oral medication Triphala Guggulu with lukewarm water for seven days. With this treatment of short duration, the patient got good results, and she got relief from pain, 
stiffness and she can do all household works without any difficulty. The patient was followed up for 11 months, and she is normal without any complaints.

\section{Procedure of Agni Karma}

After taking written consent, the patient is taken into a comfortable position. Part preparation was done by using betadine solution. Injection TT $0.5 \mathrm{ml}$ intramuscular was given. After that, mark the maximum tenderness points using a marker pen at the affected area. The clean and sterile hypodermic needles of no -26 are pricked at a depth of $0.5-1 \mathrm{~cm}$ at already marked points with the distance of $0.5 \mathrm{~cm}$. using an electric probe which is attached to bipolar electric cautery is touched to the needles at a fraction of seconds to transfer electric current to needles. Likewise 2-3 rounds, the probe was touched to needles based on the patients capacity. After that, all needles are removed and discarded. Kumari Swarasa or Ghrita was applied to the burning sites after the procedure. Appropriate precautions were taken not to produce Asamyak dagdha Vrana. Vatavardhaka Ahara-Vihara was restricted during the procedure, and the whole follow up period.

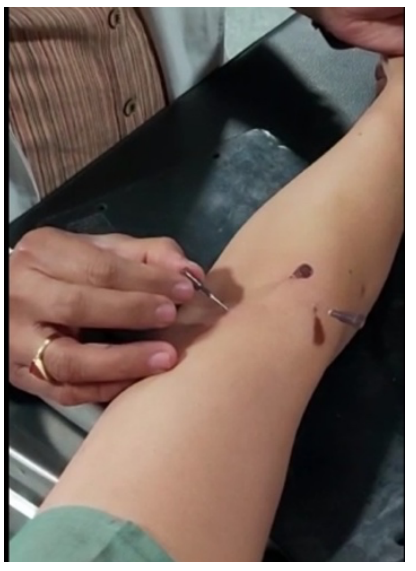

Figure 1: Insertion of needles

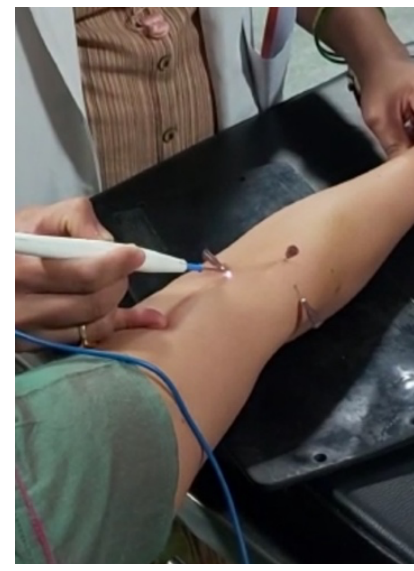

Figure 2: Touching the probe to needles

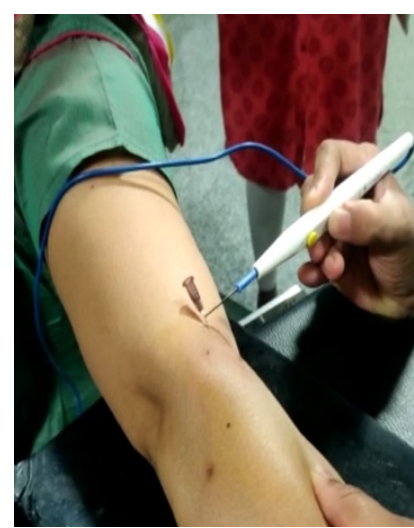

Figure 3: Touching the probe to needles

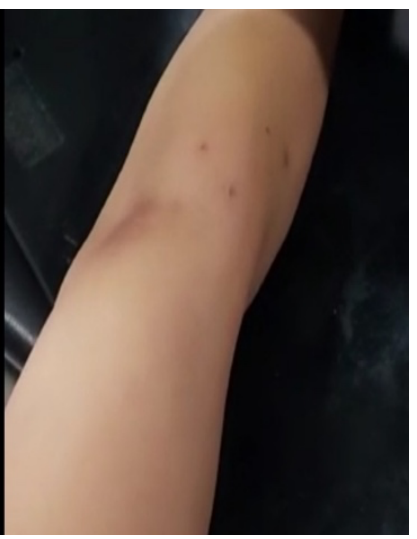

Figure 4: Burn marks after removal of needles

\section{DISCUSSION}

Tennis elbow can be developed because of injury and inflammation added with degenerative changes at the origin of the tendon of extensor carpi radialis bravis muscle. It causes restricted movements of the affected arm and pain. In Ayurveda, it is compared with Snayugatavata and caused due to vitiation of Vata associated with Kapha dosha. Vata and Kapha are considered important factors for the causation of Shoola (pain) and Shotha (inflammation) in the body. In such conditions, Agnikarma Chikitsa is indicated ${ }^{10}$. Agni has the qualities such as Ushna (hot), Teekshna (sharp), Sukshma (finest) and Ashukari ${ }^{11}$ (Quick-acting), which are opposite to the qualities of Vata and Kapha dosha so that Agnikarma reduces pain and stiffness by pacifying the Vata and Kapha.

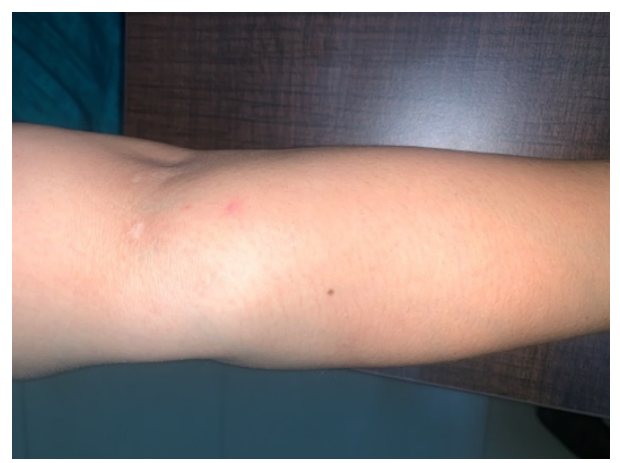

Figure 5: Minimal scar mark after 11 months of procedure

In Agnikarma, therapeutic heat is transferred to Twak dhatu (skin) and deeper structures with the help of Suchi (needles). It soothes the Amadosha and Srotovaigunya, which reduce pain and inflammation. Multiple superficial burn wounds were healed within 3-5 days, and the scar marks disappeared in due-coarse of time (2-3 weeks). Patients were advised not to do hard work, lift heavy weights, and twist movements for six months.

\section{CONCLUSION}

Tennis elbow is common in young and middle-aged people. It causes more pain and stiffness to the patients, and also it hampers daily routine activities. Viddagni karma using a needle and electric cautery is a modified technique of Agnikarma procedure based on Acharya Chakra Datta. It consumes less time, minor burn wounds, and scar marks than other classical Agnikarma methods. 


\section{REFERENCES}

1. Maheswari J, Essential Orthopaedics, 3rd Ed. New Delhi: Mehta Publisher; 2003. p. 257.

2. Allander E, Prevalence, incidence, and remission rates of some common rheumatic diseases or syndromes. Scand J Rheumatol 1974; 3:145-53.

3. Bjordal JM, Lopes-Martins RA, Joensen J, Couppe C, Ljunggren AE, Stergioulas A, et al. A systematic review with procedural assessments and meta-analysis of low-level laser therapy in lateral elbow tendinopathy (tennis elbow). BMC Musculoskeletal Disorder 2008; 9:75.

4. Ebnezar J. Text Book of Orthopaedics, 4th ed., Chap. 17. Delhi: Jaypee Brothers Medical Publishers (P) Ltd.; 2003. P 195.[Reprint].

5. Available from: http://orthoinfo.aaos.org/topic.cfm topic- A Tennis Elbow 00068 downloaded dt 28/5/2012. [Last accessed on $2013 \mathrm{Jan}]$.

6. Tripathi B. Charaka Samhita, Vol. 2. Chikitsa sthana 28 chapter Sloka No. 16: Varanasi: Chaukhamba Surbharati Publication; 2009. P 937.
7. Coonrad RW, Hooper WR. Tennis elbow: Its course, natural history, conservative and surgical management. J Bone Joint Surg Am 1973; 55:1177-82.

8. Cyriax J. The pathology and treatment of tennis elbow. J Bone Joint Surg Am 1936; 18:921-40.

9. Ambikadutta Shastri, Sushruta Samhita (purbardha). 9th ed. Chikitsa sthana chapter 4 Sloka No 8. Varanasi: Chaukhamba Sanskrit Samsthan; 1995. P 26.

10. Gupta PD. Agnikarma Technological innovation. Nagpur: Prabha Publication; 1992. P 35.

11. Sehgal U, Rajgopal M, Dwivedi RR. Role of Agni karma and ajamodadivati in the management of sandhigata Vata w.s.r. to cervical spondylosis. Ayu 2009; 30:345-9.

\section{Cite this article as:}

Poornima Jalawadi et al. Management of tennis elbow by Viddagnikarma: A case study. Int. J. Res. Ayurveda Pharm. 2022;13(1):10-12 http://dx.doi.org/10.7897/2277-4343.13013

Disclaimer: IJRAP is solely owned by Moksha Publishing House - A non-profit publishing house, dedicated to publishing quality research, while every effort has been taken to verify the accuracy of the content published in our Journal. IJRAP cannot accept any responsibility or liability for the site content and articles published. The views expressed in articles by our contributing authors are not necessarily those of IJRAP editor or editorial board members. 